\title{
Immunological Relationships Among $\beta$-Galactosidases in Members of the Genus Lactobacillus
}

\author{
M. E. NADER de MACIAS, G. PERDIGON, G. OLIVER, AND A. A. P. DE RUIZ HOLGADO* \\ Centro de Referencia para Lactobacilos, Chacabuco 145, 4000 Tucumán, República Argentina, and Instituto de \\ Microbiología, Facultad de Bioquímica, Química y Farmacia, Universidad Nacional de Tucumán, Tucumán, \\ República Argentina
}

\begin{abstract}
We prepared antisera against purified inducible $\beta$-galactosidases from Lactobacillus murinus ATCC 35020 , Lactobacillus bulgaricus ATCC $11842^{\mathrm{T}}$ ( $\mathrm{T}=$ type strain), and Lactobacillus helveticus $\mathrm{ATCC} 15009^{\mathrm{T}}$ and used these antisera to measure the levels of immunological relatedness between the reference enzymes and $\beta$-galactosidases from various lactobacilli. Crude extracts from 11 species of lactobacilli, 7 wild-type strains isolated from Tafí cheese (Tucumán, Argentina), and 4 biotypes isolated from the guts of rats were tested against $\beta$-galactosidase antisera from $L$. murinus, $L$. bulgaricus, and $L$. helveticus. Pairwise comparisons between cross-reacting crude extracts were done by using double-diffusion assays. These comparisons permitted the recognition of antigenic specificity groups based on the $\beta$-galactosidases of various nomenspecies of lactobacilli; some of the species gave bands of nonidentity. The results of microcomplement fixation experiments in which we used two of the three antisera supported the results obtained with the double-diffusion assays and provided quantitative estimations of the antigenic relationships within the various $\beta$-galactosidases. From the combined results obtained with the antisera, a composite phylogenetic map of the antigenic relationships among the $\beta$-galactosidases from lactobacilli was prepared. This map agreed with the maps for the following two other constitutive enzymes: fructose diphosphate aldolase (J. London and $\mathrm{K}$. Kline, Bacteriol. Rev. 37:453-478, 1973) and D-(-)-lactic dehydrogenase (F. Gasser and C. Gasser J. Bacteriol. 106:113-125, 1971).
\end{abstract}

In previous studies, the fructose diphosphate aldolase of Streptococcus faecalis (7) and the D-(-)-lactic dehydrogenases of Lactobacillus leichmanii, Lactobacillus jensenii, and Lactobacillus fermentum (5) were used as references to establish evolutionary relationships among lactic acid bacteria by determining the degrees of immunological reactivity between these enzymes and specific antisera. In these studies the authors demonstrated that all lactic acid bacteria are members of a single evolutionary group. These authors used a sensitive method, namely, immunological analysis for the detection of structural homologies among proteins.

The available data suggest that among isofunctional proteins, the degree of cross-reactivity is inversely related to the number of differences in the amino acid sequences (1).

Other methods suitable for studying evolutionary relationships among bacterial groups are determination of guanineplus-cytosine contents of deoxyribonucleic acids (4) and deoxyribonucleic acid reassociation $(3-5,7,9)$. Unfortunately, these methods provide little information concerning the degree of sequence similarity (16).

The present investigation was carried out to determine phylogenetic relationships among lactobacilli by analyzing a common inducible enzyme, $\beta$-galactosidase, using microcomplement fixation and Ouchterlony techniques.

\section{MATERIALS AND METHODS}

Microorganisms. The Lactobacillus strains used in this study are listed in Table 1.

Culture media and growth conditions. The basic medium used for growth of the organisms has been described previously by Raibaud et al. (13). Lactose $(0.5 \%)$ was added to the medium to induce the enzyme. After $15 \mathrm{~h}$ at $37^{\circ} \mathrm{C}$, the cells were harvested by centrifugation at $7,000 \times g$ for 10

\footnotetext{
* Corresponding author.
}

min at $4^{\circ} \mathrm{C}$. The cells were washed twice in $50 \mathrm{mM}$ phosphate buffer ( $\mathrm{pH} 7.0)$.

Preparation of cell-free extracts. The cells harvested by centrifugation $(40 \%, \mathrm{wt} / \mathrm{vol})$ were suspended in phosphate buffer ( $\mathrm{pH} 7.0$ ) and disrupted in a Megason Ultrasonic sonifier at $100 \mathrm{~W}$ and $4^{\circ} \mathrm{C}$ for $30 \mathrm{~min}$ with 3 -min intervals after each 5-min exposure.

Cell debris was removed by centrifugation at $30,000 \times g$ for $30 \mathrm{~min}$ at $4^{\circ} \mathrm{C}$ and was stored at $-70^{\circ} \mathrm{C}$ until it was needed.

Isolation and purification of $\beta$-galactosidases. The Lactobacillus strains used for $\beta$-galactosidase purification and to prepare antisera were Lactobacillus murinus ATCC 35020, Lactobacillus helveticus ATCC $15009^{\mathrm{T}}$ and Lactobacillus bulgaricus ATCC $11842^{\mathrm{T}}$.

The following procedure was used to purify $L$. murinus $\beta$-galactosidase (10): precipitation with solid ammonium sulfate between 40 and $65 \%$ saturation, chromatography over Ultrogell ACA 34 and diethylaminoethyl-Sephadex A-50, and affinity chromatography over agarose-p-aminophenyl- $\beta$-D-thiogalactoside. Polyacrylamide gel electrophoresis was used for purity control (Fig. 1) (10).

For purification of $L$. helveticus $\beta$-galactosidase the steps were as follows (11): precipitation with solid ammonium sulfate between 20 and $80 \%$ saturation, chromatography on a diethylaminoethyl-cellulose column equilibrated with $50 \mathrm{mM}$ phosphate buffer (pH 7.0) and eluted with a 0 to $0.6 \mathrm{M} \mathrm{NaCl}$ linear gradient, filtration through Sepharose 6B, and affinity chromatography with agarose- $p$-aminophenyl- $\beta$-D-thiogalactoside. Polyacrylamide gel electrophoresis was used for purity control $(10,11)$.

The $\beta$-galactosidase of $L$. bulgaricus was purified by the procedure used for purification of the $L$. helveticus enzyme.

Enzymatic activity was determined by using the synthetic substrate $o$-nitrophenyl- $\beta$-D-galactopyranoside. The enzyme was incubated for $10 \mathrm{~min}$ at $37^{\circ} \mathrm{C}$ with $1 \mathrm{mM} \mathrm{o}$-nitrophenyl- 
TABLE 1. Bacterial strains used in this study

\begin{tabular}{|c|c|c|}
\hline Species or biotype & Strain" & Isolated from: \\
\hline L. acidophilus & ATCC $4356^{\mathrm{T}}$ & \\
\hline L. bulgaricus & ATCC $11842^{\mathrm{T}}$ & \\
\hline L. bulgaricus & CRL 403 & $\begin{array}{l}\text { Local Argentine } \\
\text { cheese }\end{array}$ \\
\hline L. bulgaricus & CRL 405 & $\begin{array}{l}\text { Local Argentine } \\
\text { cheese }\end{array}$ \\
\hline L. bulgaricus & CRL 406 & $\begin{array}{l}\text { Local Argentine } \\
\text { cheese }\end{array}$ \\
\hline \multicolumn{3}{|c|}{ L. casei subsp. casei ATCC $393^{\mathrm{T}}$} \\
\hline L. casei subsp. casei & iCRL 237 & Tafí cheese \\
\hline $\begin{array}{l}\text { L. casei subsp. pseu- } \\
\text { doplantarum }\end{array}$ & -CRL 203 & Tafí cheese \\
\hline $\begin{array}{l}\text { L. casei subsp. } \\
\text { rhamnosus }\end{array}$ & CRL 207 & Tafí cheese \\
\hline L. cellobiosus & ATCC $11739^{\mathrm{T}}$ & \\
\hline L. fermentum & ATCC $14931^{\mathrm{T}}$ & \\
\hline L. helveticus & ATCC $15009^{\mathrm{T}}$ & \\
\hline L. lactis & ATCC $12315^{\mathrm{T}}$ & \\
\hline L. leichmannii & ATCC 7830 & \\
\hline L. murinus & ATCC $35020(=$ CNRZ 313) & \\
\hline L. plantarum & ATCC 10241 & \\
\hline L. plantarum & CRL 123 & Tafí cheese \\
\hline L. salivarius & ATCC $11742^{\mathrm{T}}$ & \\
\hline $\begin{array}{c}\text { "Thermobacterium } \\
\text { biotype } 1\end{array}$ & CNRZ 320 & Gut of rat ${ }^{b}$ \\
\hline $\begin{array}{l}\text { "Thermobacterium" } \\
\text { biotype } 2\end{array}$ & CNRZ 236 & Gut of $\mathrm{rat}^{b}$ \\
\hline $\begin{array}{l}\text { "Thermobacterium" } \\
\text { biotype } 3\end{array}$ & CNRZ 361 & Gut of rat ${ }^{b}$ \\
\hline $\begin{array}{l}\text { "Thermobacterium" } \\
\text { biotype } 4\end{array}$ & CNRZ 133 & Gut of rat ${ }^{b}$ \\
\hline
\end{tabular}

"ATCC, American Type Culture Collection; CRL, Centro de Referencia para Lactobacilos; CNRZ, Centre National de la Recherche Zootechnique.

"Isolated by Raibaud et al. (14).

$\beta$-D-galactopyranoside in $50 \mathrm{mM}$ monopotassium disodium phosphate buffer ( $\mathrm{pH}$ 7.0) (final volume, $0.75 \mathrm{ml}$ ). The reaction was stopped by adding $0.5 \mathrm{M} \mathrm{Na}_{2} \mathrm{CO}_{3}$. Absorbance was determined at $440 \mathrm{~nm}$. The standard curve was obtained with $o$-nitrophenol.

One unit of enzymatic activity was defined as $1 \mu \mathrm{mol}$ of $o$-nitrophenol released at $37^{\circ} \mathrm{C}$ from $o$-nitrophenyl- $\beta$-Dgalactopyranoside per $\mathrm{ml}$ per min of reaction.

Preparation of antisera. Antiserum against each $\beta$ galactosidase was prepared by injecting $1 \mathrm{mg}$ of highly purified enzyme into two New Zealand white rabbits. The antigen was suspended in an equal volume of Freund complete adjuvant, and the rabbits were injected with $1 \mathrm{ml}$ each time. A priming dose was given in each footpad, and a boosting dose was administered 8 days later subcutaneously in four different sites on the back. On days 21 and 28 the same dose was injected in the footpad. The rabbits were bled from the central ear artery on days 35, 37, and 39 after boosting; $10 \mathrm{ml}$ of serum was obtained at each bleeding, and these samples were stored in 1-ml tubes at $-70^{\circ} \mathrm{C}$.

Antiserum specificity and purity were tested against $\beta$ galactosidase by the Ouchterlony test and microcomplement fixation. This procedure produced a single precipitation line on immunodiffusion plates and the same microcomplement fixation curve with both purified enzyme and crude cell-free extracts prepared as described above.

Quantitative precipitin tests were performed to determine antibody concentration (6).

Immunodiffusion. Immunodiffusion tests were conducted at room temperature by using the Ouchterlony double-diffusion technique (10). Portions (approximately $3 \mathrm{ml}$ ) of $1.25 \%$ aqueous agarose solutions were pipetted onto glass slides; 20 $\mu \mathrm{l}$ of a solution containing $250 \mu \mathrm{g}$ of $\beta$-galactosidase crude extract per $\mathrm{ml}$ ( 10 to $50 \mathrm{U}$ of enzymatic activity) was added to each antigen well. The central well received $20 \mu \mathrm{l}$ of undiluted antiserum. Precipitin lines were examined after 24 and $48 \mathrm{~h}$ of incubation at room temperature.

Microcomplement fixation. Microcomplement fixation experiments were performed by using the technique of Wasserman and Levine (16), as modified by Rogosa (personal communication). Two anti- $\beta$-galactosidase sera, which were obtained with $L$. murinus ATCC 35020 and $L$. bulgaricus ATCC $11842^{\mathrm{T}}$, were tested against 22 Lactobacillus strains. The guinea pig complement was titrated to obtain $50 \%$ lysis under standard conditions, and $2.5 \mathrm{U}$ was routinely used.

After centrifugation for $90 \mathrm{~min}$ at $20,000 \mathrm{rpm}$ to eliminate anti-complementary activity, the crude extracts of each strain were diluted to give a range of 1 to $40 \mu \mathrm{g}$ of protein for the homologous and heterologous antigens to assay with every antiserum dilution.

Enzymatic activity was detectable with $1 \mu \mathrm{g}$ of protein.

Each homologous system and each strain were tested with four different antiserum dilutions to determine the optimal concentration that fixed between 50 and $90 \%$ of the complement (Fig. 2).

The anti- $\beta$-galactosidase of $L$. bulgaricus ATCC $11842^{\mathrm{T}}$ was used at a final dilution of $1: 10,000$, and the anti- $\beta$ galactosidase of $L$. murinus ATCC 35020 was used at a final dilution of 1:10,500; these antisera were compared with each crude extract (Fig. 3 and 4 ).

The results of the microcomplement fixation experiments were expressed as indexes of dissimilarity (ID) (2), which were determined by using the following expression: $\log$ ID =

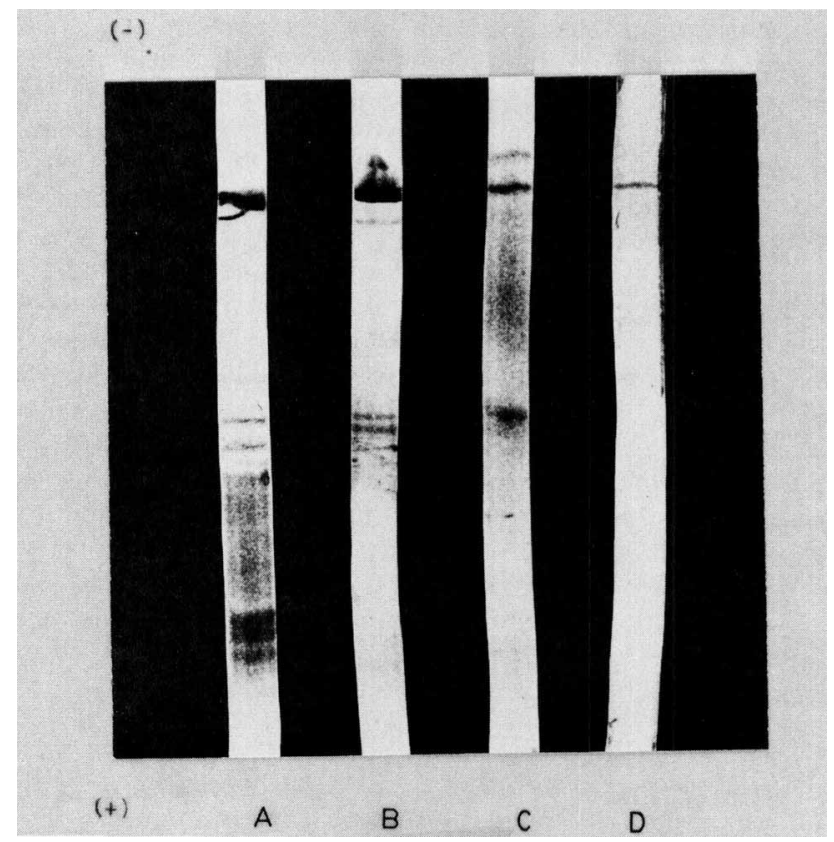

FIG. 1. Polyacrylamide (7.5\%) gel electrophoresis of samples from steps in the purification of $\beta$-galactosidase from $L$. murinus ATCC 35020. Lane A, 40 to $65 \%\left(\mathrm{NH}_{4}\right)_{2} \mathrm{SO}_{4}$ fraction; lane $\mathrm{B}$, peak fraction eluted by Ultrogell ACA 34 column chromatography; lane $\mathrm{C}$, peak fraction eluted by diethylaminoethyl-Sephadex A-50 column chromatography; lane $\mathrm{D}$, peak fraction eluted by affinity chromatography. The gels were stained with $0.1 \%$ Coomassie brillant blue R-250 and destained with $50 \%$ methanol- $7.5 \%$ acetic acid. 
$\left(Y_{H}-Y_{h}\right) / M+\log \left(X_{H} / X_{h}\right)$, where $Y_{H}$ and $Y_{h}$ are the percentages of complement fixed by the homologous and heterologous antigens, respectively, $X_{H}$ and $X_{h}$ are the antiserum concentrations used with the homologous and heterologous antigens, respectively, and $M$ is the resultant slope of a semilogarithmic plot in which the log of the antiserum dilution used in the homologous system is plotted against the percentage of complement fixed.

The values of $M$ for the $L$. bulgaricus and $L$. murinus systems were 174 and 97 , respectively.

The units of immunological distance were calculated by using the mathematical expression derived by Wilson et al. (17), where the immunological distance is equal to $\log _{10}$ of the dissimilarity index multiplied by 100 .

\section{RESULTS}

Comparative Ouchterlony double-diffusion experiments with each of the three antisera against $\beta$-galactosidase preparations (Fig. 5A through E) showed that the anti- $\beta$ galactosidase of $L$. bulgaricus ATCC $11842^{\mathrm{T}}$ had identical specificity with $L$. bulgaricus ATCC $11842^{\mathrm{T}}$, Lactobacillus

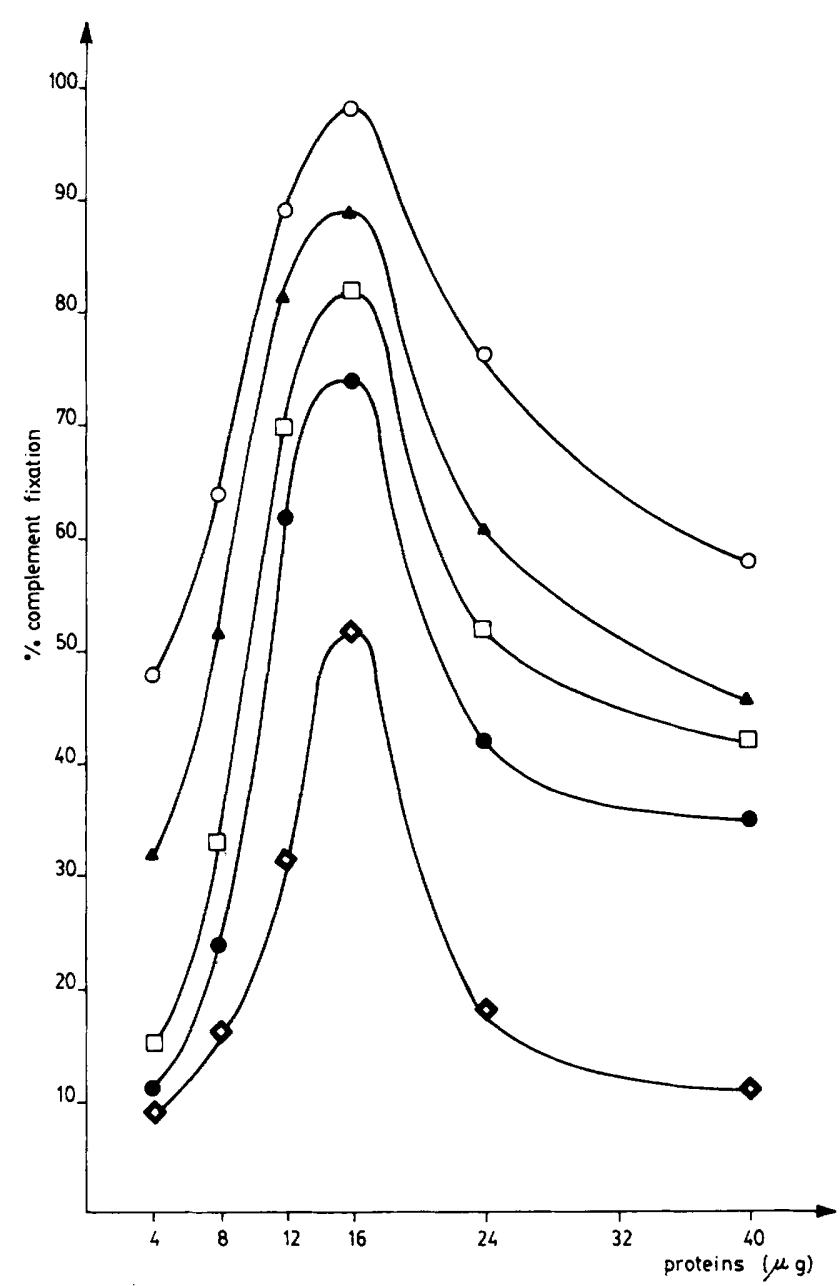

FIG. 2. Microcomplement fixation curves obtained with different dilutions of anti- $\beta$-galactosidase from $L$. bulgaricus ATCC $11842^{\mathrm{T}}$ and $\beta$-galactosidase from $L$. bulgaricus ATCC $11842^{\mathrm{T}}$ (1 to $40 \mu \mathrm{g}$ of antigen). Symbols: $O$, antiserum diluted $1: 6,000 ; \boldsymbol{\Lambda}$, antiserum diluted 1:7,000; $\square$, antiserum diluted 1:8,000;, antiserum diluted $1: 10,000 ; \diamond$, antiserum diluted $1: 12,500$.

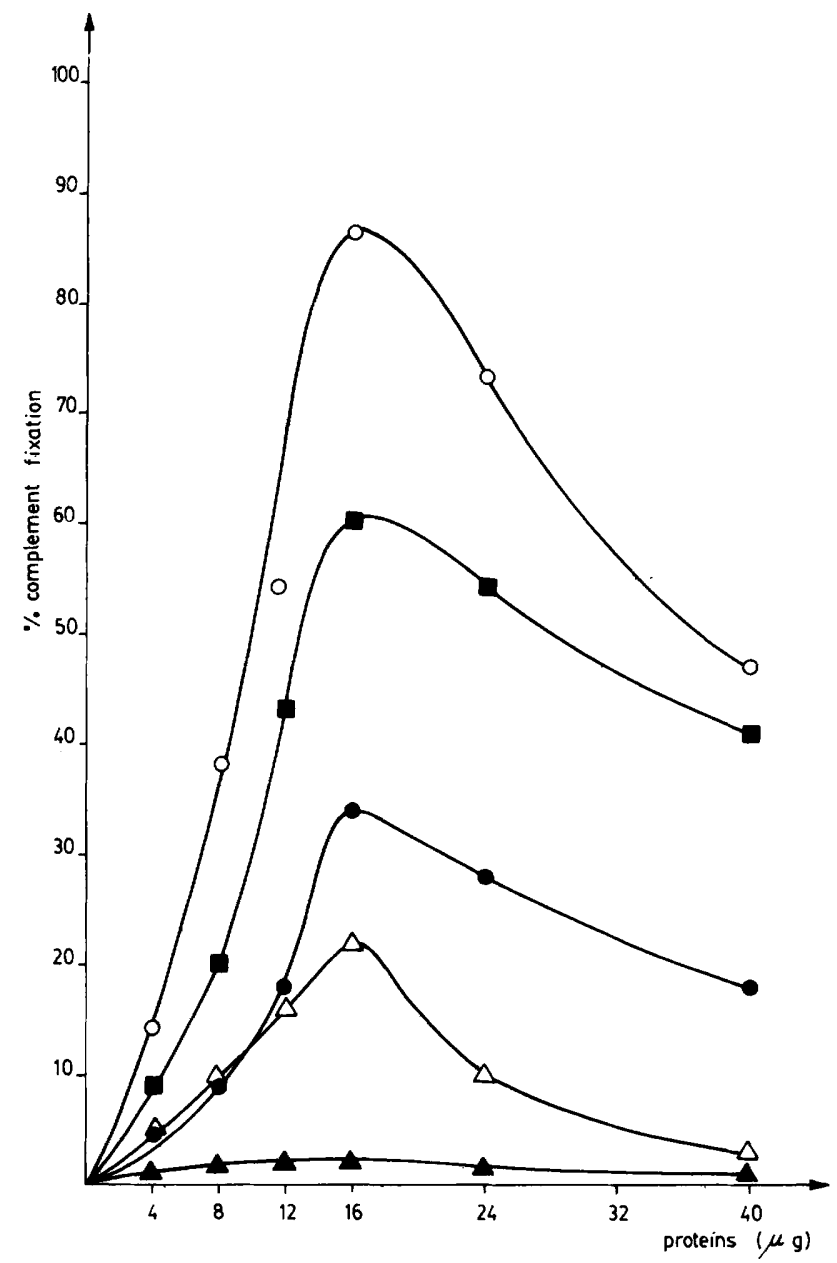

FIG. 3. Microcomplement fixation curves obtained with anti- $\beta$ galactosidase from $L$. bulgaricus ATCC $11842^{\mathrm{T}}$ (diluted $1: 10,000$ ) and $\beta$-galactosidases from collection strains. Symbols: $O$, homologous $\beta$-galactosidase from $L$. bulgaricus ATCC $11842^{\mathrm{T}}$; $\mathbf{\square}$, heterologous $\beta$-galactosidase from $L$. lactis ATCC $12315^{\mathrm{T}} ; \boldsymbol{\bullet}, L$. acidophilus ATCC $4356^{\mathrm{T}} ; \triangle, L$. casei subsp. casei ATCC 393 ${ }^{\mathrm{T}} ; \boldsymbol{\Lambda}, L$. murinus ATCC 35020.

lactis ATCC $12315^{\mathrm{T}}$, and L. leichmannii ATCC 7830, suggesting that the $\beta$-galactosidases of these strains are immunologically homologous.

Cross-reactions with a single spur were produced with the same antiserum when extracts of $L$. fermentum ATCC $14931^{\mathrm{T}}$, Lactobacillus casei subsp. casei ATCC $393^{\mathrm{T}}$, and Lactobacillus acidophilus ATCC $4356^{\mathrm{T}}$ were placed in adjacent wells. Formation of two spurs, one directed toward each antigen well, was observed with $L$. helveticus ATCC $15009^{\mathrm{T}}$, suggesting a reaction of nonidentity.

Extracts from $L$. murinus ATCC 35020 , Lactobacillus salivarius ATCC $11742^{\mathrm{T}}$, and Lactobacillus plantarum ATCC 10241 did not give any precipitation, indicating that each had heterologous proteins.

The results of Ouchterlony immunodiffusion with the anti- $\beta$-galactosidase of $L$. bulgaricus ATCC $11842^{\mathrm{T}}$ are shown in Fig. 6.

When anti- $\beta$-galactosidase antiserum from $L$. helveticus ATCC $15009^{\mathrm{T}}$ was compared with the crude extracts, only $L$. helveticus showed an identity reaction, whereas $L$. bulgaricus ATCC $11842^{\mathrm{T}}$, L. lactis ATCC $12315^{\mathrm{T}}$, L. leich- 


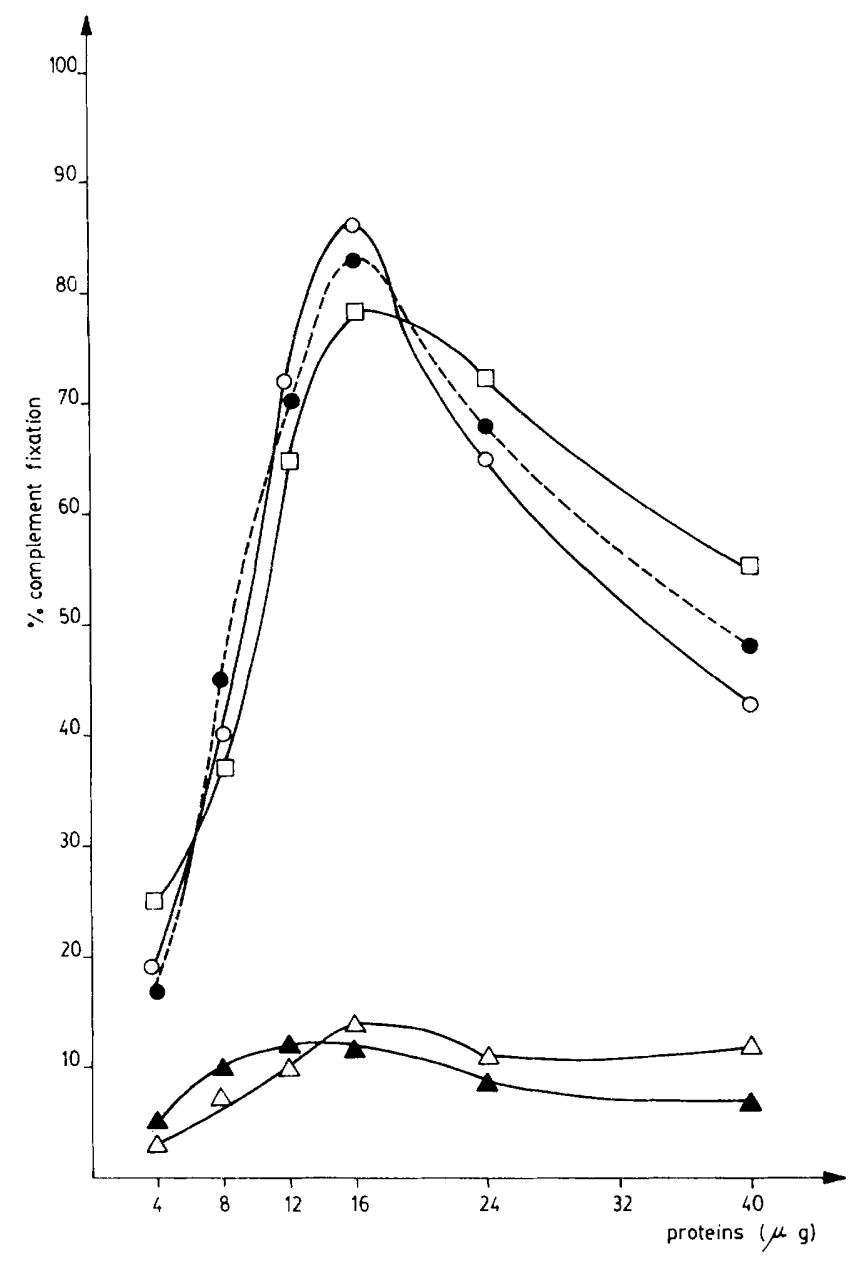

FIG. 4. Microcomplement fixation curves obtained with anti- $\beta$ galactosidase from $L$. bulgaricus ATCC $11842^{\mathrm{T}}$ (diluted $1: 10,000$ ) and $\beta$-galactosidases from wild-type strains. Symbols: $O$, homologous $\beta$-galactosidase from $L$. bulgaricus ATCC $11842^{\mathrm{T}} ; \boldsymbol{\bullet}, \beta$ galactosidase from $L$. bulgaricus CRL $405 ; \square, \beta$-galactosidase from $L$. bulgaricus CRL $403 ; \boldsymbol{\Lambda}, \beta$-galactosidase from $L$. plantarum $\mathrm{CRL}$ $123 ; \triangle, \beta$-galactosidase from $L$. casei subsp. pseudoplantarum $C R L$ 203.

mannii ATCC 7830, L. fermentum ATCC $14931^{\mathrm{T}}$, and $L$. casei subsp. casei ATCC $393^{\mathrm{T}}$ gave cross-reactions with a single spur. No strain gave a cross-reaction with two spurs.

No reaction was obtained with $L$. murinus ATCC 35020 , $L$. plantarum ATCC $10241, L$. acidophilus ATCC $4356^{\mathrm{T}}, L$. salivarius ATCC $11742^{\mathrm{T}}$, or Lactobacillus cellobiosus ATCC $11739^{\mathrm{T}}$ (Fig. 7).

None of the extracts studied reacted when they were tested with anti- $\beta$-galactosidase from $L$. murinus ATCC 35020. This antiserum gave precipitin lines only with the B-galactosidase from L. murinus (Fig. $5 \mathrm{~A}$ and $\mathrm{B}$ ).

L. casei subsp. casei CRL 237 and L. plantarum CRL 123, strains which were isolated from a local cheese (Tafí, Tucumán, Argentina), as well as L. bulgaricus CRL 403, CRL 405, and CRL 406 (collection strains from the Center of Reference for Lactobacilli), showed behavior similar to that of the collection strains when they were tested with the three antisera. L. casei subsp. pseudoplantarum CRL 203 and $L$. casei subsp. rhamnosus CRL 207, wild-type strains isolated from Tafí cheese, did not react with any of the antisera. The same result was obtained with the biotypes belonging to the
Thermobacterium group ("Thermobacterium" biotype 2 strain CNRZ 236, "Thermobacterium" biotype 3 strain CNRZ 361, "Thermobacterium" biotype 1 strain CNRZ 320 , and "Thermobacterium" biotype 4 strain CNRZ 133), which were isolated from the guts of rats.

The microcomplement fixation technique was used to detect minor differences among the antigenic determinants of the various $\beta$-galactosidase proteins by using two $\beta$ galactosidase antisera corresponding to $L$. bulgaricus ATCC $11842^{\mathrm{T}}$ and $L$. murinus ATCC 35020.

By using the results of the experiments described above, the indexes of dissimilarity and the immunological distances were calculated (Table 2).

\section{DISCUSSION}

An immunological comparison of the amino acid sequences of isofunctional proteins allows the creation of evolutionary trees.

Champion and co-workers (2) demonstrated that quantitative immunological techniques could be readily adapted to measure structural similarities among related proteins. The immunological method is a rapid, easy, and sensitive technique which allows microbiologists to compare isologous enzymes from a large number of bacterial species.

The results obtained when the $\beta$-galactosidases from $L$. bulgaricus ATCC $11842^{\mathrm{T}}$ and L. murinus ATCC 35020 were used as immunological references were used to determine the levels of relatedness among 22 Lactobacillus strains and to establish, with a considerable degree of certainty, the immunological relationships within this group of bacteria.

In this study, the immunodiffusion technique was used qualitatively to establish a hierarchical order and to determine whether proteins had diverged from each other (5-8); microcomplement fixation was used to quantify the degree of relatedness.

There is a correlation between the results obtained with the immunodiffusion and microcomplement fixation methods. However, it is generally accepted that the Ouchterlony technique is not very sensitive; therefore, the more sensitive quantitative immunochemical procedure (microcomplement fixation) can be used to detect minor antigenic differences which might not be observed with the Ouchterlony method. The quantitative nature of these assays also permitted us to calculate the immunological distances among antigenically distinct forms of $\beta$-galactosidase.

Table 2 shows that with the anti- $\beta$-galactosidase from $L$. bulgaricus ATCC $11842^{\mathrm{T}}$, as well as with that from $L$. murinus ATCC 35020, there was a high degree of homology between the $L$. bulgaricus reference and $L$. bulgaricus $C R L$ 403, CRL 405, and CRL 406 (collection strains from the Center of Reference for Lactobacilli), L. lactis ATCC $12315^{\mathrm{T}}$, and L. leichmannii ATCC 7830.

L. casei subsp. casei ATCC $393^{\mathrm{T}}$, L. casei subsp. casei CRL 237 (wild type), L. acidophilus ATCC 4356', L. helveticus ATCC $15009^{\mathrm{T}}$, and $L$. fermentum ATCC $14931^{\mathrm{T}}$ are antigenically less related to $L$. bulgaricus ATCC $11842^{\mathrm{T}}$ than the group described above, but they are related to each other.

L. murinus ATCC 35020, the "Thermobacterium" biotypes tested ("Thermobacterium" biotype 2 strain CNRZ 236, "Thermobacterium" biotype 3 strain CNRZ 361, "Thermobacterium" biotype 1 strain CNRZ 320, and "Thermobacterium" biotype 4 strain CNRZ 133; isolated from the same habitat), L. salivarius ATCC $11742^{\mathrm{T}}$, L. cellobiosus ATCC $11739^{\mathrm{T}}$, L. plantarum ATCC 10241 , L . plantarum wild-type strain CRL 123, L. casei subsp. pseudoplantarum CRL 203, 

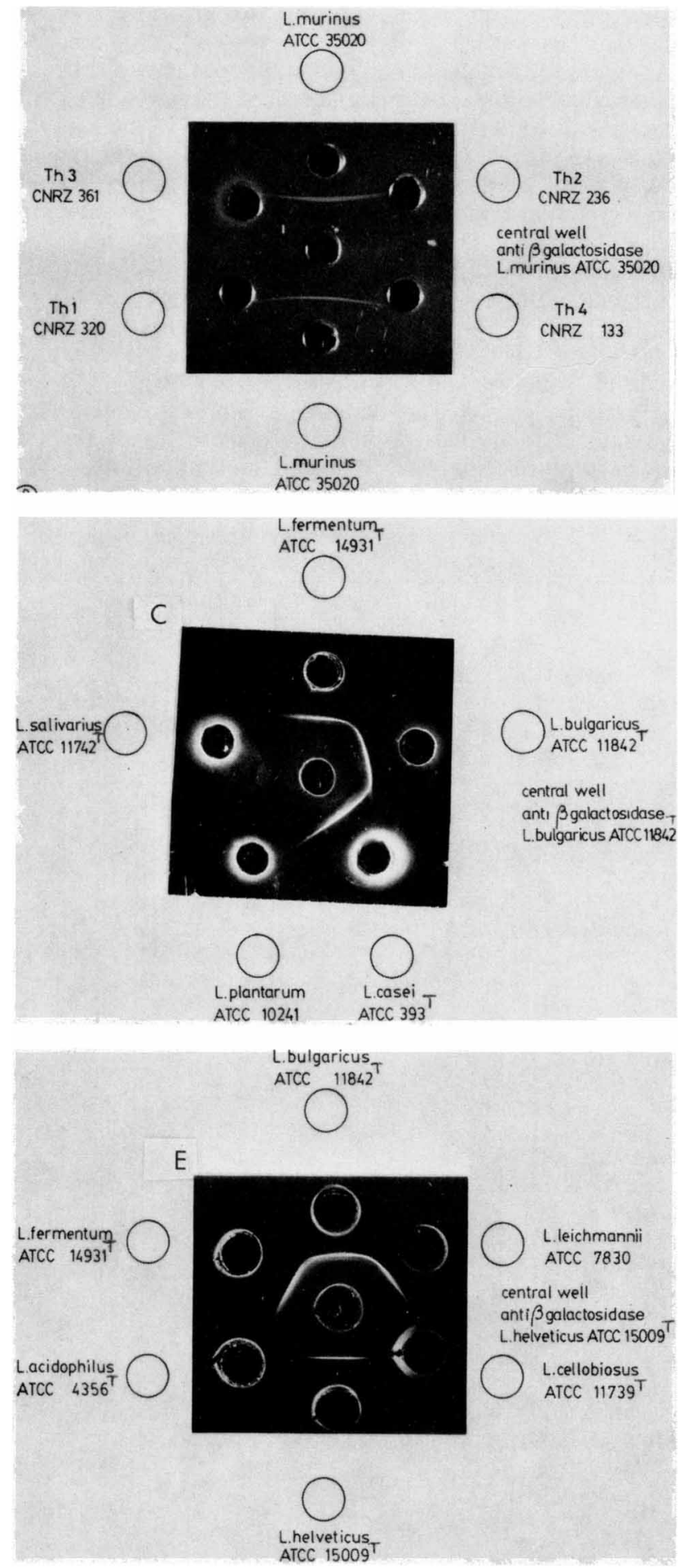

and $L$. casei subsp. rhamnosus CRL 207 (isolated from Tafí cheese) showed the lowest levels of homology with both reference proteins. The high indexes of dissimilarity indicate that these strains belong in another group of lactic acid bacteria.

The results of the immunodiffusion experiments combined with the indexes of dissimilarity or immunological distances allowed us to draw a phylogenetic map in which the different groups of lactobacilli are separated. A map showing the

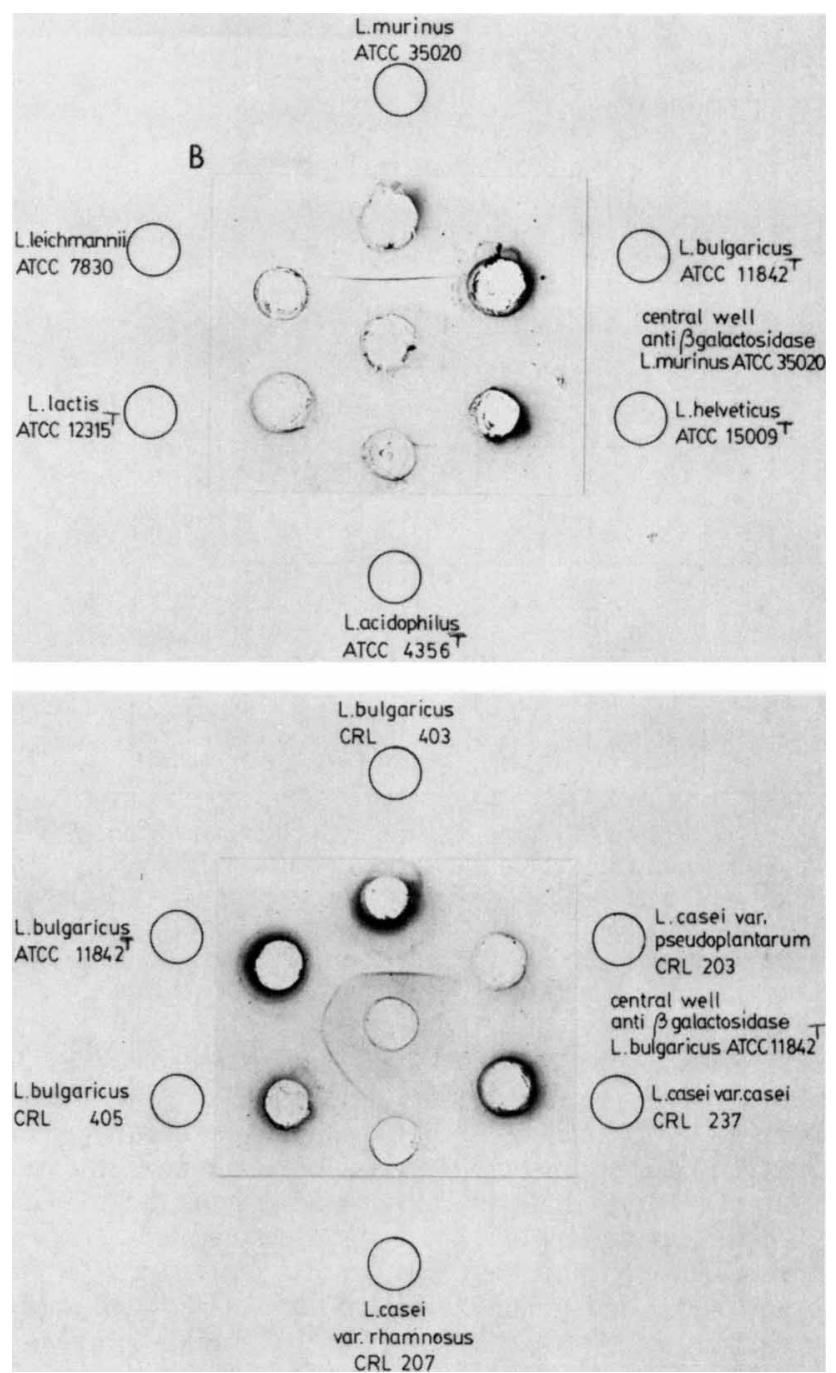

FIG. 5. Examples of the precipitin patterns obtained in Ouchterlony experiments with antisera prepared against the $\beta$-galactosidases of $L$. bulgaricus ATCC $11842^{\mathrm{T}}$, L. helveticus ATCC $15009^{\mathrm{T}}$, and $L$. murinus ATCC 35020 . (A and B) The central well contained anti- $\beta$-galactosidase serum from $L$. murinus ATCC 35020 , which shows a precipitin line only with $L$. murinus. Th1, "Thermobacterium" biotype 1; Th2, "Thermobacterium" biotype 2; Th3, "Thermobacterium" biotype 3; Th4, "Thermobacterium" biotype 4. (C and D) The central well contained $\beta$-galactosidase antiserum from L. bulgaricus ATCC $11842^{\mathrm{T}}$. (C) Single spur. (D) Reaction without spur formation, indicating an homologous group. (E) The central well contained $\beta$-galactosidase antiserum from $L$. helveticus ATCC $15009^{\mathrm{T}}$. The reactions indicate an homologous group and another strain without precipitin lines.

phylogenetic relationships derived from our experiments is shown in Fig. 8 and 9.

The existence of immunological similarities among $L$. bulgaricus ATCC $11842^{\mathrm{T}}$, L. lactis ATCC $12315^{\mathrm{T}}$, and $L$. leichmannii ATCC 7830 was confirmed by using two types of $\beta$-galactosidase antiserum. Our results agree with those of London and Kline (7) and those of Gasser and Gasser (5), who used aldolase and lactase dehydrogenase, respectively.

We are surprised with the position of $L$. fermentum ATCC $14931^{\mathrm{T}}$ and with the scattered positions of different strains of L. casei among this group, because of the heterofermentative and facultative homofermentative nature, respectively, of these organisms. This fact demonstrates that $\beta$ - 


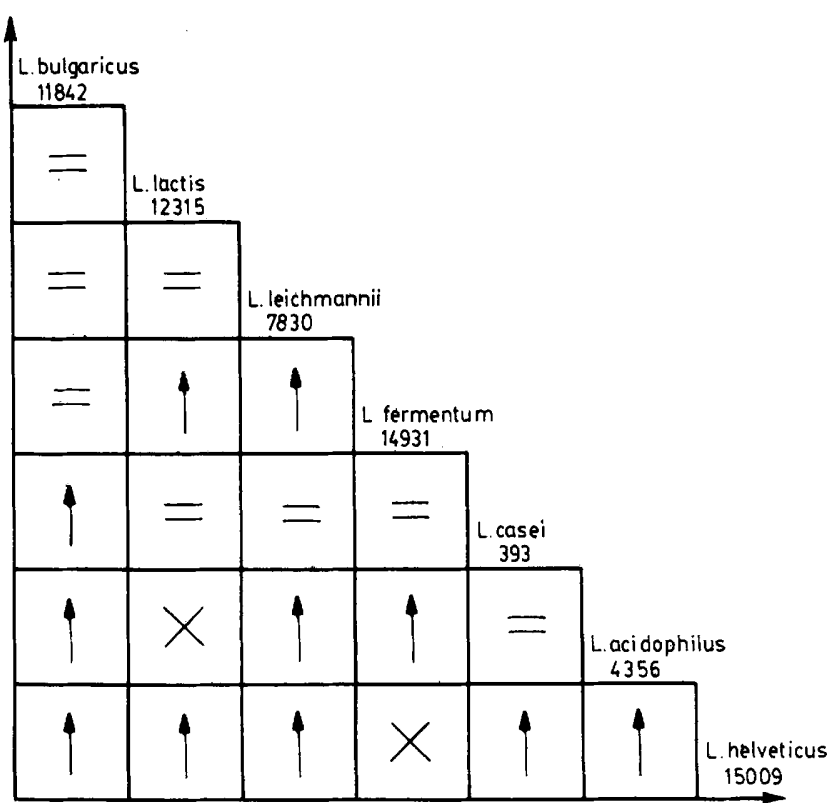

FIG. 6. Results of cross-reactions (Ouchterlony tests) with $L$. bulgaricus ATCC $11842^{\mathrm{T}}$ anti- $\beta$-galactosidase serum. An equals sign indicates a cross-reaction without spur formation (total identity reaction). An arrow indicates a cross-reaction with spur formation (partial identity reaction). A multiplication sign indicates a cross-reaction with the formation of two spurs (nonidentity reaction).

galactosidase is an enzyme that has experienced few modifications throughout evolution, as evidenced by its almost unchanged occurrence in homo- and heterofermentative lactic acid bacteria, whereas the same phenomenon does not occur in enzymes that participate in subsequent metabolism.

There are groups of lactobacilli less related to these strains. These groups have diverged from the $L$. bulgaricus group (5-8). They include $L$. acidophilus ATCC $4356^{\mathrm{T}}$ in one group, L. casei subsp. casei ATCC $393^{\mathrm{T}}$ and CRL 237 in a second group, and L. helveticus ATCC $15009^{\mathrm{T}}$ in a third group. This speculation is based on the partial identity

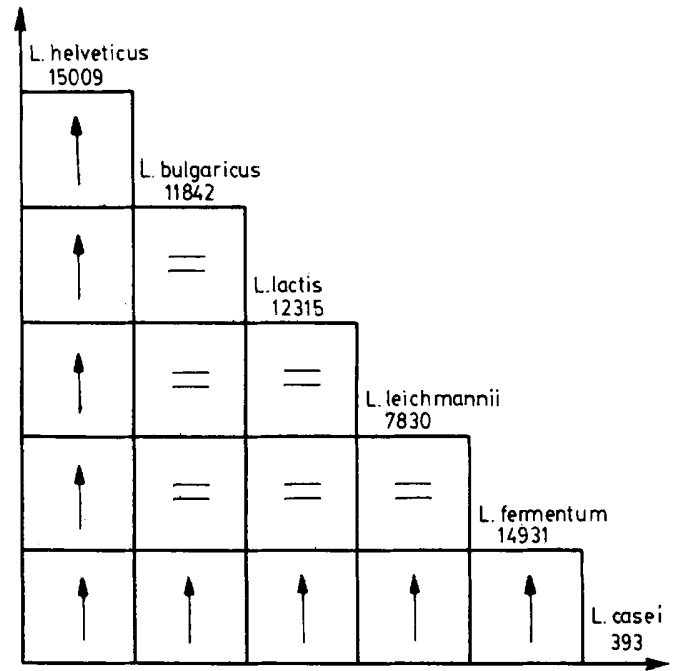

FIG. 7. Results of cross-reactions (Ouchterlony tests) with $L$. helveticus ATCC $15009^{\mathrm{T}}$ anti- $\beta$-galactosidase serum. For an explanation of symbols see the legend to Fig. 6 . results obtained in immunodiffusion experiments and on indexes of dissimilarity.

Another group did not react with either of the two antisera in immunodiffusion experiments because the immunological distance was too great in microcomplement fixation assays. In the map they are far from the $L$. bulgaricus reference. However, all of these lactobacilli were probably derived from a common ancestor, because they can all cross-react in microcomplement fixation assays.

We found that $L$. casei subsp. casei ATCC 393 and CRL 273 are in a different group than $L$. casei subsp. rhamnosus CRL 237 and L. casei subsp. pseudoplantarum CRL 203. These findings are in agreement with those of London and Mayer (8), who worked with the malic enzyme.

It must be emphasized that our schemes are tentative. Two antisera against two different $\beta$-galactosidases are not enough to reveal complete phylogenetic relationships.

TABLE 2. Quantitative estimation of antigenic homologies of certain $\beta$-galactosidases by microcomplement fixation

\begin{tabular}{|c|c|c|c|c|}
\hline \multirow{3}{*}{ Strain } & \multicolumn{4}{|c|}{ Antigenic similarity determined with: } \\
\hline & \multicolumn{2}{|c|}{$\begin{array}{c}\text { Anti- } L \text {. bulgaricus } \\
\text { ATCC } 11842^{\mathrm{T}} \\
\beta \text {-galactosidase }\end{array}$} & \multicolumn{2}{|c|}{$\begin{array}{l}\text { Anti- } L . \text { murinus } \\
\text { ATCC } 35020 \\
\beta \text {-galactosidase }\end{array}$} \\
\hline & $\begin{array}{l}\text { Index of } \\
\text { dissimi- } \\
\text { larity }\end{array}$ & $\begin{array}{l}\text { Immuno- } \\
\text { logical } \\
\text { distance }\end{array}$ & $\begin{array}{l}\text { Index of } \\
\text { dissimi- } \\
\text { larity }\end{array}$ & $\begin{array}{l}\text { Immuno- } \\
\text { logical } \\
\text { distance }\end{array}$ \\
\hline $\begin{array}{l}\text { L. acidophilus ATCC } \\
4356^{\mathrm{T}}\end{array}$ & 3.16 & 50 & 7.45 & 87 \\
\hline $\begin{array}{l}\text { L. bulgaricus ATCC } \\
11842^{\mathrm{T}}\end{array}$ & 1.0 & 0 & 7.24 & 86 \\
\hline L. bulgaricus CRL 403 & 1.35 & 13 & 7.29 & 86 \\
\hline L. bulgaricus $\mathrm{CRL} 405$ & 1.27 & 11 & 7.69 & 89 \\
\hline L. bulgaricus CRL 406 & 1.35 & 13 & 7.31 & 87 \\
\hline $\begin{array}{l}\text { L. casei subsp. casei } \\
\text { ATCC } 393^{\mathrm{T}}\end{array}$ & 2.68 & 43 & 8.82 & 95 \\
\hline $\begin{array}{l}\text { L. casei subsp. casei } \\
\text { CRL } 237\end{array}$ & 2.87 & 46 & 8.78 & 94 \\
\hline $\begin{array}{l}\text { L. casei subsp. pseudo- } \\
\text { plantarum CRL } 203\end{array}$ & 4.69 & 67 & 4.62 & 66 \\
\hline $\begin{array}{l}\text { L. casei subsp. rhamno- } \\
\text { sus CRL } 207\end{array}$ & 5.42 & 73 & 4.36 & 64 \\
\hline $\begin{array}{l}\text { L. cellobiosus ATCC } \\
11739^{\mathrm{T}}\end{array}$ & 8.90 & 95 & 2.63 & 42 \\
\hline $\begin{array}{l}\text { L. fermentum ATCC } \\
14931^{\mathrm{T}}\end{array}$ & 2.27 & 36 & 6.20 & 79 \\
\hline $\begin{array}{l}\text { L. helveticus ATCC } \\
15009^{\mathrm{T}}\end{array}$ & 2.43 & 38 & 7.88 & 90 \\
\hline L. lactis ATCC $12315^{\mathrm{T}}$ & 1.87 & 27 & 7.36 & 87 \\
\hline $\begin{array}{l}\text { L. leichmannii ATCC } \\
7830\end{array}$ & 1.76 & 24 & 6.87 & 84 \\
\hline L. murinus ATCC 35020 & 9.57 & 98 & 1.0 & 0 \\
\hline $\begin{array}{l}\text { L. plantarum ATCC } \\
10241\end{array}$ & 6.12 & 78 & 4.67 & 67 \\
\hline L. plantarum CRL 13 & 4.94 & 69 & 4.56 & 66 \\
\hline $\begin{array}{l}\text { L. salivarius ATCC } \\
11742^{\mathrm{T}}\end{array}$ & 5.59 & 75 & 4.07 & 61 \\
\hline $\begin{array}{l}\text { "Thermobacterium" bio- } \\
\text { type } 1 \text { strain CNRZ } \\
320\end{array}$ & & & 4.30 & 63 \\
\hline $\begin{array}{l}\text { "Thermobacterium" bio- } \\
\text { type } 2 \text { strain CNRZ } \\
236\end{array}$ & & & 3.90 & 59 \\
\hline $\begin{array}{l}\text { "Thermobacterium" bio- } \\
\text { type } 3 \text { strain CNRZ } \\
361\end{array}$ & & & 3.77 & 58 \\
\hline $\begin{array}{l}\text { "Thermobacterium" bio- } \\
\text { type } 4 \text { strain CNRZ } \\
133\end{array}$ & & & 3.74 & 57 \\
\hline
\end{tabular}




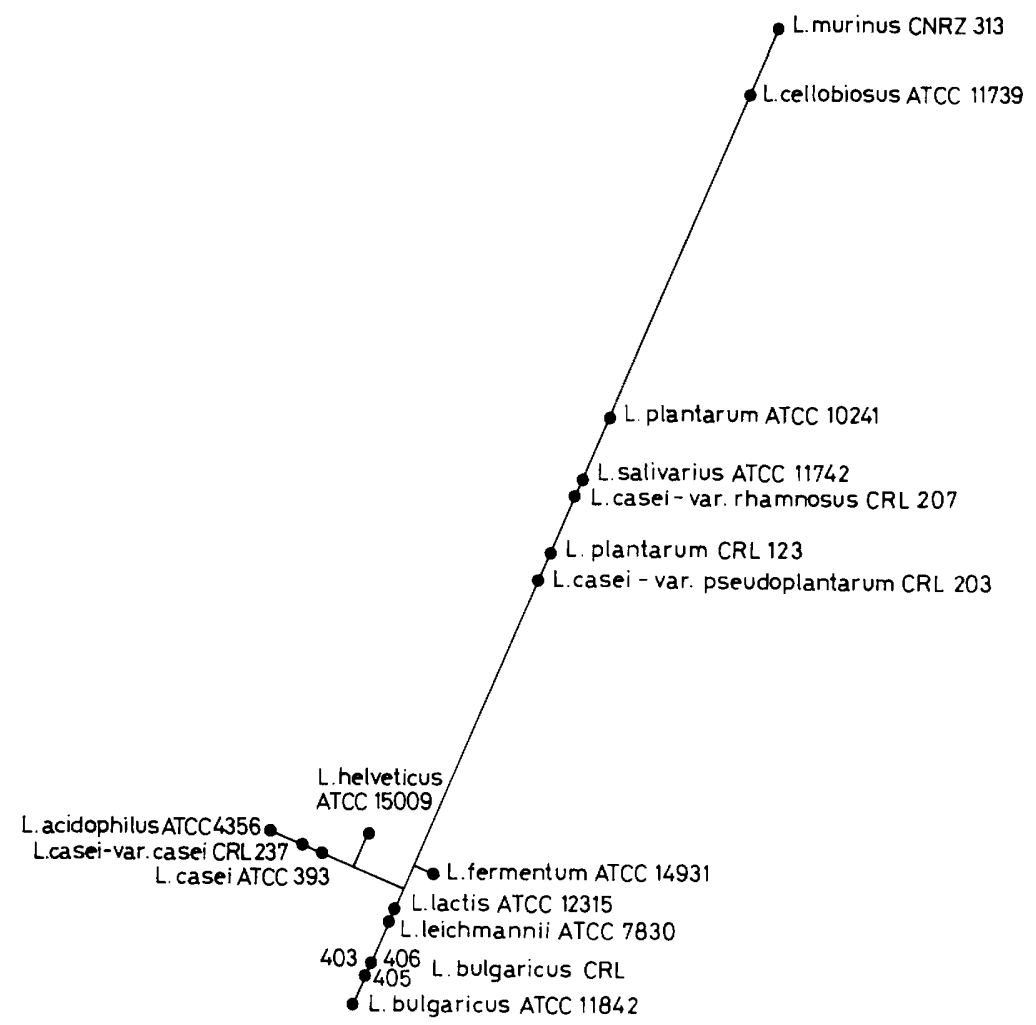

FIG. 8. Map based on the results of microcomplement fixation experiments (Table 2) and of immunodiffusion experiments with $L$. bulgaricus ATCC $11842^{\mathrm{T}}$ anti- $\beta$-galactosidase serum (Fig. 6).

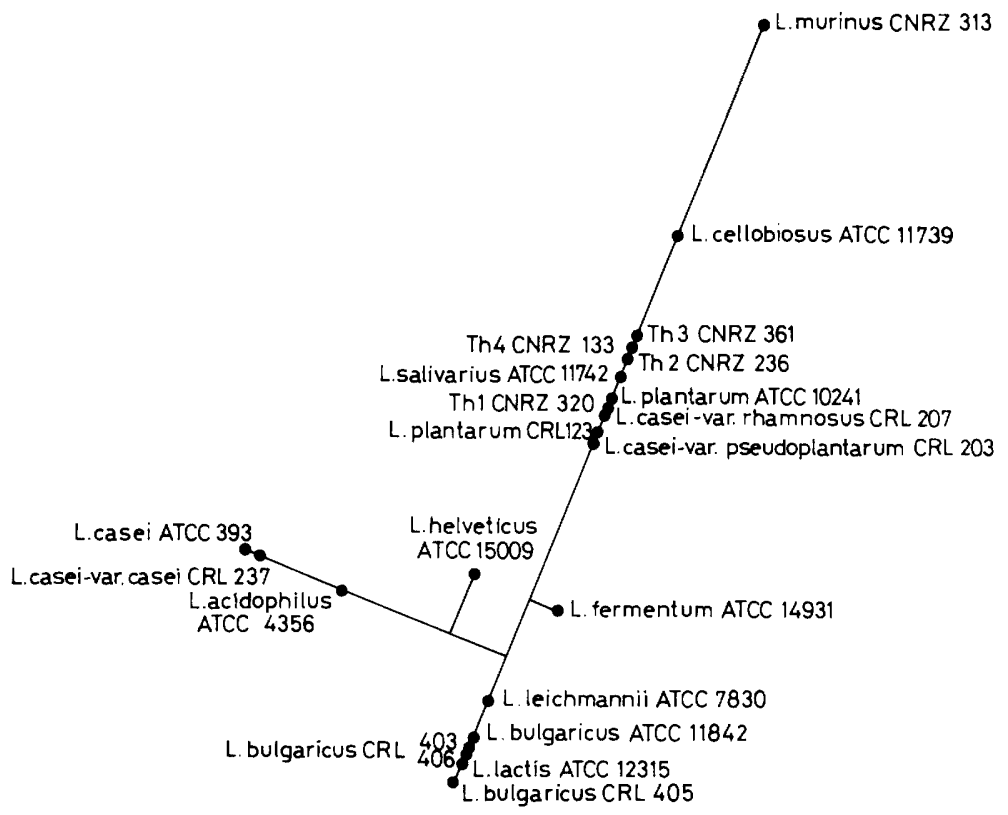

FIG. 9. Map based on the results of microcomplement fixation experiments with $L$. murinus ATCC 35020 anti- $\beta$-galactosidase serum (Table 2). Th1, "Thermobacterium" biotype 1; Th2, "Thermobacterium" biotype 2; Th3, "Thermobacterium" biotype 3; Th4, "Thermobacterium" biotype 4 .

Our study, in which we used $\beta$-galactosidase, confirmed the phylogenetic map and allowed us to acquire more knowledge about the evolutionary process at the molecular level.

\section{ACKNOWLEDGMENTS}

G.P., G.O., and A.A.P.d.R.H. are Career Investigators of the Consejo Nacional de Investigaciones Científicas y Técnicas of Ar- 
gentina. M.E.N.d.M. is a Fellow of the Consejo Nacional de Investigaciones Científicas y Técnicas of Argentina. We thank Ricardo Margni for suggestions and critical reading of this paper.

This work was supported by research grant 10234/82-5 from the Consejo Nacional de Investigaciones Cientificas y Técnicas de la Republica Argentina.

\section{LITERATURE CITED}

1. Arnheim, N., E. Prager, and A. Wilson. 1969. Immunological prediction of sequence differences among proteins: chemical comparison of chicken, quail and pheasant lysozymes. J. Biol. Chem. 244:2085-2094.

2. Champion, A. B., K. L. Soderberg, and A. C. Wilson. 1975. Immunological comparison of azurins of known amino acid sequence. J. Mol. Evol. 5:291-305.

3. Garvie, E. 1976. Hybridization between the deoxyribonucleic acids of some strains of heterofermentative lactic acid bacteria. Int. J. Syst. Bacteriol. 26:112-116.

4. Garvie, E., V. Zezula, and V. A. Hill. 1974. Guanine-plus-cytosine content of the deoxyribonucleic acid of the leuconostocs and some heterofermentative lactobacilli. Int. J. Syst. Bacteriol. 24:248-251.

5. Gasser, F., and C. Gasser. 1971. Immunological relationships among lactic dehydrogenases in the genera Lactobacillus and Leuconostoc. J. Bacteriol. 106:113-125.

6. Heidelberger, M., H. P. Treffers, and M. Mayer. 1940. A quantitative theory of the precipitin reaction. VII. The egg albumin antibody reaction in antisera from the rabbit and horse. J. Exp. Med. 71:217-275.

7. London, J., and K. Kline. 1973. Aldolase of lactic acid bacteria: a case history in the use of an enzyme as an evolutionary marker. Bacteriol. Rev. 37:453-478.
8. London, J., E. Y. Meyer, and S. R. Kulczyk. 1971. Detection of relationships between Streptococcus faecalis and Lactobacillus casei by immunological studies with two forms of malic enzyme. J. Bacteriol. 108:196-201.

9. McCarthy, B., and E. Bolton. 1963. An approach to the measurement of genetic relatedness among organisms. Proc. Natl. Acad. Sci. U.S.A. 50:156-164.

10. Nader de Macías, M. E., M. C. Manca de Nadra, A. M. Strasser de Saad, A. A. Pesce de Ruíz Holgado, and G. Oliver. 1983. Isolation and purification of $\beta$-galactosidase of Lactobacillus murinus CNRZ 313. Curr. Microbiol. 9:99-104.

11. Nader de Macías, M. E., M. C. Manca de Nadra, A. M. Strasser de Saad, A. A. Pesce de Ruíz Holgado, and G. Oliver. 1983. Isolation and properties of $\beta$-galactosidase of a strain of $\mathrm{Lac}$ tobacillus helveticus isolated from natural whey starter. J. Appl. Biochem. 5:275-281.

12. Ouchterlony, O. 1949. Antigen-antibody reaction in gels. Acta Pathol. Microbiol. Scand. 26:507-515.

13. Raibaud, P., M. Caulet, J. V. Galpin, and G. Mocquot. 1961. Studies on the bacterial flora of the alimentary tract of pig. II. Streptococci-selective enumeration and differentiation of the dominant group. J. Appl. Bacteriol. 24:285-306.

14. Raibaud, P., O. V. Galpin, R. Ducluzeau, G. Mocquot, and G. Oliver. 1973. Le genre Lactobacillus dans le tube digestif du rat. Ann. Inst. Pasteur Paris 124A:83-109.

15. Singer, C., and B. Ames. 1971. Sunlight ultraviolet and bacterial DNA base ratios. Science 170:822-826.

16. Wasserman, E., and L. Levine. 1961. Quantitative microcomplement fixation and its use in the study of antigenic structure by specific antigen-antibody inhibition. J. Immunol. 87:290-295.

17. Wilson, A., N. Kaplan, L. Levine, A. Pesce, M. Reichlin, and W. Allison. 1964. Evolution of lactic dehydrogenase. Fed. Proc. Fed. Am. Soc. Exp. Biol. 23:1258-1266. 